\title{
Relative Expression of TLR9 Gene in Natural Sub-clinical and Clinical Cases of Bovine Mastitis caused by Escherichia coli
}

\author{
R. Lakshmi ${ }^{1}$ *and K.K. Jayavardhanan ${ }^{2}$ \\ ${ }^{1}$ Department of Veterinary Biochemistry, Rajiv Gandhi Institute of Veterinary \\ Education and Research, Puducherry - 605 009, India \\ ${ }^{2}$ Department of Veterinary Biochemistry, College of Veterinary and Animal Sciences, \\ Thrissur, Kerala - 680651, India \\ *Corresponding author
}

\begin{tabular}{|c|c|}
\hline & A B S T R A C T \\
\hline & \multirow{6}{*}{$\begin{array}{l}\text { Mastitis is an inflammatory condition of the mammary tissue resulting in several } \\
\text { physiological and metabolic changes, trauma, and more frequently it is caused by } \\
\text { contagious or environmental pathogenic microorganisms, including Gram-positive and } \\
\text { Gram-negative bacteria. Escherichia coli are most common infectious agents responsible } \\
\text { for sub-clinical and clinical mastitis in dairy forms. The first line of defense against } \\
\text { mammary bacterial infection was initiated by innate resistance of mammary gland. Toll- } \\
\text { like receptors (TLRs) are a key family of innate immune proteins, serving as the principal } \\
\text { recognition site of pathogens and signalling functions, enabling the host to eliminate } \\
\text { pathogens. Hence, this study assessed the expression of an important } T L R 9 \text { gene in } \\
\text { spontaneous bovine sub-clinical and clinical mastitis caused by E. coli. The total RNA was } \\
\text { isolated from milk somatic cells converted as cDNA using oligo (dT) primers. Relative } \\
\text { quantitation of mRNA of } T L R 9 \text { was analysed by RT-qPCR system. The mRNA expression } \\
\text { of } T L R 9 \text { gene in sub-clinical mastitis was higher ( } 3.22 \text { fold) than clinical case (1.09 fold) } \\
\text { when compared to normal bovine case. Relative difference in the expression of TLR9 gene } \\
\text { in sub-clinical and clinical mastitis was found to be significant (P } \leq 0.05 \text { ). During sub- } \\
\text { clinical stage of infection the expression of TLR9 gene was at high level, therefore most of } \\
\text { the sub-clinical mastitis subsided by itself without precipitating into clinical mastitis. TLR } \\
\text { mediated signalling cascades will be fundamental to understand the host immune response } \\
\text { against bovine mastitis. }\end{array}$} \\
\hline Keywords & \\
\hline $\begin{array}{l}\text { TLR9, } \\
\text { Expression, } \\
\text { Mastitis and } \\
\text { E. coli }\end{array}$ & \\
\hline Article Info & \\
\hline $\begin{array}{l}\text { Accepted: } \\
\text { 17 April } 2017 \\
\text { Available Online: } \\
10 \text { May } 2017\end{array}$ & \\
\hline & \\
\hline
\end{tabular}

\section{Introduction}

Mastitis is one of the major endemic diseases of dairy cattle and its prevalence is increasing in parallel with the development of new high milk producing breeds. Escherichia coli is a gram-negative most common infectious agents responsible for subclinical and clinical mastitis in dairy forms (Bradley et al., 2007). Innate resistance of mammary gland is one of the first line of host defense against mammary bacterial infection. Toll-like receptors (TLRs) are a key family of innate immune proteins, serving as the principal recognition site of pathogens and signalling functions, enabling the host to eliminate pathogens (Hallman et al., 2001). Currently, 13 TLRs have been identified in mammals (TLRI to TLR13) of which 10 TLRs are reported in cattle (Tabeta et al., 2004; Roach et al., 2005). Of these, 
TLR9 is the main pathogen recognition receptors (PRR), for bacteria and virus. TLR9 has been demonstrated as a receptor for bacterial DNA comprising unmethylated $\mathrm{CpG}$ dinucleotides (Hemmi et al., 2000). Specifically, TLR9 links the innate and adaptive immune system by favouring a Th1 immune response and increasing the production of autoantibody. Bacterial DNA differs from mammalian DNA by its 20 -foldgreater frequency of unmethylated $\mathrm{CpG}$ sequences (Wagner, 1999). These CpG sequences activate a signaling cascade via transcription factors NF- $\kappa \mathrm{B}$ and $\mathrm{AP}-1$ and stimulate the proliferation of $\mathrm{B}$ cells and the secretion of proinflammatory cytokines IL-6, IL-12, and tumour necrosis factor alpha are required to eliminate an invading pathogen (Zhao et al., 1997; Krieg, 2002). Hence in this study, we investigate the expression of TLR 9 gene in natural infected $E$. coli cases of subclinical and clinical mastitis.

\section{Materials and Methods}

\section{Sample collection and identification}

Milk samples were collected from University farm and Veterinary Dispensaries and Teaching Veterinary Clinical Complex of the College of Veterinary and Animal Sciences at Thrissur Kerala. The collected milk samples subjected for California mastitis test (CMT) and somatic cell count (SCC) for detection of sub-clinical, clinical, and normal animals. Further the milk samples subjected for microbiological and biochemical examination for identification of E. coli (Quinn et al., 2002)

\section{RNA isolation and CDNA synthesis}

From the somatic cells, total RNA was isolated using TRIzol reagent of SIGMA (As per the manufacturer's protocol). The quality and concentration of extracted RNA was determined by agarose gel electrophoresis (1.5\%) and nanodrop spectrophotometer. Residual DNA was removed from extracted total RNA by treatment with DNase1. For synthesis of cDNA, one microgram of total RNA was taken by using Revert Aid first strand cDNA synthesis kit.

\section{Primers design and synthesis}

Primers for RT-qPCR of TLR9 and $\beta$-actin were designed from published bovine mRNA sequences available from GenBank. Designing and checking of primers were done with Primer3 software (Table 1).

\section{RT-qPCR}

Real-time PCR was carried out in an Illumina Eco® Q- RT PCR system. The reaction solution was prepared on ice, and consisted of: 10 microlitre of $2 \mathrm{X}$ SYBR Green PCR master mix, 10 pmole (1microlitre) of each gene-specific primers, 2 microlitre of cDNA template and 7 microlitre of nuclease free water to final volume of 20 microlitre. The reaction mixtures were incubated in 48 well plate at $95^{\circ} \mathrm{C}$ for $10 \mathrm{~min}$ followed by 40 cycles of 95 for $30 \mathrm{sec}, 58$ for $30 \mathrm{sec}$ and 72 for $1 \mathrm{~min}$ with fluorescence recording at the end of each cycle. All reactions were performed in triplicates. After 40 amplification cycles, all the samples were submitted to dissociation curve analysis to verify the absence of non-specific products and primer dimers. The protocol for melt curve analysis was $95^{\circ} \mathrm{C}$ for $15 \mathrm{sec}, 55^{\circ} \mathrm{C}$ for $15 \mathrm{sec}$ followed by $95^{\circ} \mathrm{C}$ for $15 \mathrm{sec}$. Data acquisition was performed during the final denaturation step.

The result was expressed at threshold cycle values $(\mathrm{Cq})$. The $\mathrm{Cq}$ value (the fractional cycle number at which the fluorescence exceeds a fixed threshold) was determined for each sample. To evaluate the relative mRNA 
expression, samples were normalized to the housekeeping gene actin and the results are presented as $\Delta \Delta \mathrm{C}_{\mathrm{q}}$ values as described (Zheng et al., 2007). The $\beta$-actin was selected as housekeeping gene because it showed a stable expression from all milk samples.

\section{Statistical analysis}

Analysis of variance was performed to test the significance of among the groups under study. Tukey's HSD (Honestly Significant Difference) was applied to test the significance between two groups. All statistical analyses were done using Statistical Product and Service Solution (SPSS) version 21.0 software.

\section{Results and Discussion}

Mastitis is an inflammatory condition of the mammary gland and that is usually caused by various bacterial infections. Among the bacterial infection, Escherichia coli is a gram- negative most common infectious agents responsible for subclinical and clinical mastitis in dairy forms (Bradley et al., 2007; Mitra et al., 2013). Innate resistance of mammary gland is one of the first line of host defense against mammary bacterial infection. Assessing the expression of important TLR 9 will be vital for improving our understanding of the early events controlling immune response.

Lactating cows were screened for sub-clinical and clinical mastitis Based on this CMT, SCC and biochemical test, 8 samples revealed the presence of $E$. coli in sub-clinical case of mastitis. Similarly, from clinical mastitis cases 5 samples showed the presence of $E$. coli. From each group of sub-clinical and clinical mastitis, three animals selected for RT-qPCR expression study. In addition milk samples from three apparently healthy crossbred cows were also selected as control for expression studies.

Table.1 Primer sequence for TLR9 and $\beta$-actin genes used in RT-qPCR

\begin{tabular}{|c|c|c|c|}
\hline \multicolumn{2}{|c|}{ Gene Name } & Sequence $\left(5^{\prime} \rightarrow 3^{\prime}\right)$ & $\begin{array}{c}\text { Expected } \\
\text { product size }\end{array}$ \\
\hline \multirow{2}{*}{ TLR9 } & $\mathrm{F}$ & AAGGCTTGAGGAACCTGGTC & \multirow{2}{*}{119 bp } \\
\hline & $\mathrm{R}$ & GTTATTGTCCCGGAGACGCA & \\
\hline \multirow{2}{*}{$\beta$-actin } & $\mathrm{F}$ & CCACACCTTCTACAACGAGC & \multirow{2}{*}{$105 \mathrm{bp}$} \\
\hline & $\mathrm{R}$ & ATCTGGGTCATCTTCTCACG & \\
\hline
\end{tabular}

Table.2 ANOVA for TLR9 gene expression in E. coli caused mastitis

\begin{tabular}{|l|c|l|l|}
\hline Source of Variation & df & MSS & F value \\
\hline Between Groups & 2 & $5.30 * *$ & 10.97 \\
\hline Within Groups & 6 & 0.48 & \\
\hline
\end{tabular}


Table.3 Expression of TLR9 gene in E. coli caused sub-clinical and clinical mastitis

\begin{tabular}{|c|c|c|c|c|c|c|}
\hline \multirow{2}{*}{ Sample } & \multicolumn{2}{|c|}{ Cq Mean \pm SE } & \multirow{2}{*}{$\Delta \mathbf{C q}$} & \multirow{2}{*}{$\Delta C q$ Me an } & \multirow[b]{2}{*}{$\Delta \Delta \mathbf{C q}$} & \multirow{2}{*}{$\mathbf{R Q}$} \\
\hline & TLR9 & $\beta$-actin & & & & \\
\hline Normal & $29.24 \pm 0.62$ & $15.94 \pm 0.03$ & 13.30 & $13.30 \pm 0.03$ & & \\
\hline \multicolumn{7}{|l|}{ Sub-Clinical } \\
\hline Case 1 & $27.21 \pm 0.08$ & $15.68 \pm 0.25$ & 11.53 & & -1.77 & 3.42 \\
\hline Case 2 & $27.53 \pm 0.27$ & $15.36 \pm 0.24$ & 12.18 & & -1.13 & 2.18 \\
\hline Case 3 & $27.19 \pm 0.10$ & $16.05 \pm 0.11$ & 11.14 & & -2.17 & 4.49 \\
\hline & & & & $11.61 \pm 0.30$ & -1.69 & $3.22 \mathrm{a}^{*}$ \\
\hline \multicolumn{7}{|l|}{ Clinical } \\
\hline Case 1 & $28.88 \pm 0.05$ & $16.04 \pm 0.07$ & 12.84 & & -0.46 & 1.38 \\
\hline Case 2 & $29.27 \pm 0.18$ & $16.31 \pm 0.02$ & 12.96 & & -0.34 & 1.27 \\
\hline Case 3 & $30.20 \pm 0.42$ & $16.46 \pm 0.01$ & 13.74 & & 0.44 & 0.74 \\
\hline & & & & $13.18 \pm 0.28$ & -0.12 & $1.09 b^{\text {ns }} c^{*}$ \\
\hline
\end{tabular}

$\mathrm{a}=$ Normal $v s$ Sub-clinical; $\mathrm{b}=$ Normal $v s$ Clinical; $\mathrm{c}=$ Sub-clinical $v s$ Clinical

Fig.1 Frequency distribution of TLR9 gene expression in E. coli caused mastitis

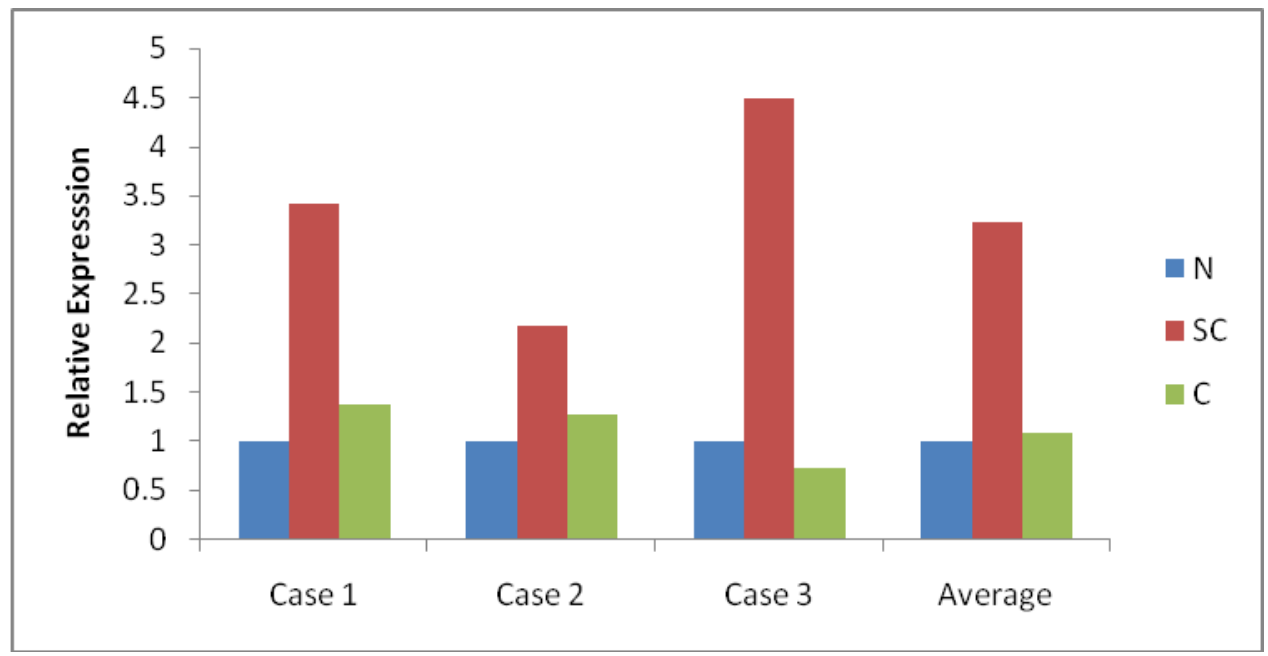

Analysis of variance for TLR9 gene revealed significant difference $(\mathrm{P} \leq 0.01)$ for expression level between the groups (Table 2). The mean values of $\mathrm{C}_{\mathrm{q}}, \Delta \mathrm{C}_{\mathrm{q}}, \Delta \Delta \mathrm{Cq}$ along with standard error and relative quantification of TLR9 expression in E. coli caused mastitis are given in table 3. The relative expression of TLR9 gene was ranged between 2.18 and 4.49 fold for sub-clinical mastitis and it was ranged from 0.74 to 1.38 fold, in clinical mastitis when compared with healthy crossbred cows (Figure 1). E. coli infected mammary gland shows mRNA levels of TLR9 was higher in sub-clinical mastitis (3.22 fold) followed by clinical mastitis ( 1.09 fold) when compared to normal animal. Relative expression of TLR9 gene was significantly $(\mathrm{P} \leq 0.05)$ higher in the sub-clinical mastitis, and also exhibits significant difference $(\mathrm{P} \leq 0.05)$ between subclinical and clinical mastitis (Figure 1). 
Toll-like receptors (TLRs) are a key family of innate immune proteins, serving as the principal recognition site of pathogens and signalling functions, enabling the host to eliminate pathogens. TLR 9 is principal receptor for bacteria and virus. In our study TLR9 was expressed with 3.22 fold upregulation in sub-clinical case of mastitis caused by $E$. coli infection. This observation was similar to a study by Zhu et al., (2008), which demonstrated that murine mammary gland infected with E. coli showed TLR9 expression significantly higher in infected group. Similarly, goat mammary gland infected with $E$. coli also showed increased expression of TLR 9 in infected group than control (Zhu et al., 2007).

The TLR9 signalling pathway was activated by the interaction of TLR 9 with CpG-DNA and proceeds through MyD88, TRAF6, IRAK, and consequently involves the activation of MAPK and NF- $\kappa \mathrm{B}$ factors followed by production of pro inflammmatory cytokines, IL-6, IL-12, and tumour necrosis factor alpha are required to eliminate an invading pathogen.

In conclusion, the study majorly underpins the significant TLR9 expression in sub-clinical mastitis eliciting prompt host immune response in $E$. coli intramammary infection. Sub-clinical mastitis is an early stage of infection, and hence the expression of TLR 9 is relatively higher at this stage compared to clinical stage. TLR9 mediated signalling cascades will be fundamental to understand the host immune response before developing effective strategies to combat mastitis.

\section{Acknowledgments}

The research work mentioned in this article is a part of the Ph.D. research work of the first author under the guidance and supervision of the second author. The first author acknowledging the INSPIRE Fellowship program of Department of Science and Technology for providing fellowship for the Ph.D program. The authors are thankful to the Dean, College of Veterinary and Animal Science for providing facilities to conduct this experiment.

\section{References}

Bradley, A.J., K.A. Leach, J.E. Breen, L.E. Green and Green, M.J. 2007. Survey of the incidence and aetiology of mastitis on dairy farms in England and Wales. Vet. Rec., 160: 253-7.

Hallman, M., M. Ramet and Ezekowitz, R.A. 2001. Toll-like receptors as sensors of pathogens. Pediatr. Res., 50: 315-321.

Hemmi, H., O. Takeuchi, T. Kawai, T. Kaisho, S. Sato, H. Sanjo, M. Matsumoto, K. Hoshino, H. Wagner, K. Takeda and Akira, S. 2000. A Tolllike receptor recognizes bacterial DNA. Nature, 408: 740-745.

Krieg, A.M. 2002 CpG motifs in bacterial DNA and their immune effects. Annu. Rev. Immunol., 20: 709-760.

Mitra, S.D., D. Velu, M. Bhuvan, N. Krithiga, A. Banerjee, R. Shome, H. Rahman, S.K. Ghosh and Shome, B.R. 2013. Staphylococcus aureus spa type t267, clonal ancestor of bovine subclinical mastitis in India. J. Appl. Microbiol., 114: 1604-15.

Quinn, P.M., B. Carter, Markey and Carter, G. 2002. Clinical veterinary microbiology mos by International Ltd, Spain pp. 96-344.

Roach, J.C., G. Glusman, L. Rowen, A. Kaur, M.K. Purcell, K.D. Smith, L.E. Hood and Aderem, A. 2005. The evolution of vertebrate Toll-like receptors. Proc. Natl. Acad. Sci. U.S.A, 102: 9577-9582.

Tabeta, K., P. Georgel, E. Janssen, X. Du, K. Hoebe, K. Crozat, S. Mudd, L. Shamel, S. Sovath, J. Goode, L. Alexopoulou, R.A. Flavell and Beutler, B. 2004. Toll-like receptors 9 and 3 as 
essential components of innate immune defense against mouse cytomegalovirus infection. Proc. Natl. Acad. Sci. USA., 101: 3516-21.

Wagner, H. 1999. Bacterial CpG DNA activates immune cells to signal infectious danger. Adv. Immunol., 73: 329-368.

Zhao, Q.J., R. Temsamani, Zhou and Agrawal, S. 1997. Pattern and kinetics of cytokine production following administration of phosphorothioate oligonucleotides in mice. Antisense Nucleic Acid Drug Dev., 7: 495-502.

Zheng, Y., D.M. Danilenko, P. Valdez, I. Kasman, J. Eastham-Anderson, J. Wu, and Ouyang, W. 2007. Interleukin-22, a $\mathrm{T}(\mathrm{H}) 17$ cytokine, mediates IL-23induced dermal inflammation and acanthosis. Nature, 445: 648-651.

Zhu, Y.M., J.F. Miao., Y.S. Zhang, Z., Li, S.X. Zou and Deng, Y.E. 2007. CpG ODN enhances mammary gland defense during mastitis induced by Escherichia coli infection in goats. Vet. Immunol. Immunop., 120: 168-176.

Zhu, Y., H. Fan., J. Miao and Zou, S. 2008. Protective effect of CpG-DNA against mastitis induced by Escherichia coli infection in a rat model. Vet. J., 175: 369-378.

\section{How to cite this article:}

Lakshmi, R. and Jayavardhanan, K.K. 2017. Relative Expression of TLR9 Gene in Natural Sub-clinical and Clinical Cases of Bovine Mastitis caused by Escherichia coli. Int.J.Curr.Microbiol.App.Sci. 6(5): 1753-1758. doi: https://doi.org/10.20546/ijcmas.2017.605.190 